\title{
PERAN KOMUNITAS SEKOLAH TERHADAP PENGURANGAN RISIKO BENCANA DI YOGYAKARTA
}

\author{
Fika Nur Indriasari1, Prima Daniyati Kusuma² \\ 1,2 Prodi DIII Keperawatan, STIKES Notokusumo Yogyakarta \\ Corresponding author: fheekha.nur@gmail.com
}

\begin{abstract}
Abstrak
Sektor pendidikan memiliki peran penting dalam menghadapi berbagai tantangan yang diakibatkan oleh terjadinya bencana dan pencegahan bahaya bencana. Sekolah merupakan lembaga tempat berbagi pengetahuan dan keterampilan, sehingga harapan bahwa sekolah menjadi panutan dalam melakukan pencegahan bencana menjadi tinggi. Guru dan tenaga kependidikan di sekolah adalah komponen yang paling penting untuk menciptakan sekolah aman. Tujuan dari penelitian ini adalah untuk mengetahui kesiapsiagaan komunitas sekolah sebagai salah satu upaya dalam pengurangan resiko bencana. Design penelitian yang digunakan adalah quasi experiment dengan rancangan one group pre and post test design. Populasi dalam penelitian ini adalah semua guru dan tenaga non kependidikan di SLB N Pembina Yogyakarta. Teknik pengambilan sampel yang digunakan adalah purposive sampling. Hasil penelitian menunjukkan bahwa nilai $p$ $>0,001$ yang berarti tidak ada perbedaan bermakna antara sebelum dan sesudah diberikan pelatihan. Selisih nilai mean pre dan post adalah 1,46 yang menunjukkan adanya peningkatan kesiapsiagaan setelah diberikan pelatihan, namun masuk dalam kategori lemah. Sebagian besar responden pernah mengikuti pelatihan sebanyak 40 orang $(76,9 \%)$. Dari data tersebut, secara umum aspek pengetahuan tentang kesiapsiagaan bencana gempa bumi, pengetahuan komunitas sekolah sudah sangat bagus. Namun ada beberapa guru dan tenaga non kependidikan yang belum mendapatkan pelatihan siaga bencana sebanyak 12 orang $(23,1 \%)$. Beberapa guru menyatakan bahwa mereka yang belum mendapatkan pelatihan adalah guru baru. Oleh karena itu, perlu adanya pengintegrasian pengurangan risiko bencana ke dalam kurikulum sekolah. Simulasi atau pelatihan diharapkan berkelanjutan setiap 3-6 bulan sekali.
\end{abstract}

Kata kunci : komunitas sekolah, pelatihan, siaga bencana

\begin{abstract}
Education sector has an important role to face some challenges due to occurence of disaster and mitigation hazards of disaster. A school is one of the place for knowledge and skill sharing, so then the hope that the school is become a centre for example in accordance with mitigation of disaster is high. Teacher and educational staff are the important parties to create a safe school. The main objective of this research is to find out the readiness of school community to reduce the risk of disaster. The design of this research is quasi experiment with the plan of one group pre and post test design. The population of this research is all teachers and staffs at SLB N Pembina Yogyakarta. Technique of sampling collection is purposive sampling. The result of this reasearch is the value of $p>0.001$ which means no different or similar result before and after training. Discrepancy of mean value in between pre and posft test is 1.46 which means there is positive impact of mitigation readiness after training eventhought small number. Most of the respondences have ever joint in training (40 peoples - 76.9\%). Based on the data, the knowledge of the readiness to face earthquake in scholl community is good. There is a few teachers and staffs which havent got any training (12 peoples - 23.1\%). Most of them are new teachers. The integration of mitigation for risk disaster within school curriculum is required. Simulation or training is advised to perform regulary every 3-6 month.
\end{abstract}

Keywords: School community, Training, Readiness to face a disaster 


\section{PENDAHULUAN}

Data Badan Meteorologi, Klimatologi, dan Geofisika (BMKG) menunjukkan bahwa aktivitas gempa di Indonesia meningkat drastis pada tahun 2017. Pada tahun 2017 terjadi peningkatan 1.352 gempa lebih banyak dibandingkan tahun 2016. Jika sebelumnnya tercatat 5,578 gempa, pada tahun 2017 tercatat 6.929 kali gempa(Safety Sign , 2018).

Pengalaman terjadinya bencana di berbagai daerah, baik bencana alam maupun non alam telah membuktikan bahwa wilayah Indonesia sangatlah berpotensi tinggi terhadap bencana. Faktor-faktor utama yang menjadi penyebab terjadinya bencana selain kondisi alam adalah kurangnya pengetahuan masyarakat terhadap bencana (Hidayati, 2006). Berbagai bencana yang telah terjadi di Indonesia memberikan banyak pembelajaran bagi masyarakat Indonesia dan dunia bahwa banyaknya korban jiwa dan harta benda dalam musibah tersebut terjadi karena kurangnya pengetahuan dan ketidaksiapan masyarakat dalam mengantisipasi bencana. Di samping itu, kejadian-kejadian bencana tersebut pun semakin menyadarkan banyak pihak tentang pentingnya perencanaan dan pengaturan dalam penanggulangan bencana (Bustami, 2011).

Fakta menunjukkan bahwa selama ini jika terjadi bencana, pemerintah dan masyarakat selalu tidak siap siaga untuk melakukan penganggulangan bencana. Hampir tidak ada sistem deteksi dini terhadap bencana yang bisa diakses langsung masyarakat. Tidak ada sistem yang membuat masyarakat terlatih menghadapi bencana. Masyarakat hanya bergantung pada respon pemerintah yang seringkali tidak siap mengambil langkah yang taktis dan strategis. Berdasarkan hal tersebut, maka sudah saatnya masyarakat memiliki kesadaran akan ancaman bencana yang selalu mengintai. Bukan hanya bergerak ketika bencana itu datang tetapi juga mengantisipasi kemungkinan bencana yang datang kapan saja. Sudah satnya masyarakat sendiri terutama yang tinggal di daerah rawan bencana memiliki kesadaran dan kesiapsiagaan terhadap bencana.

Penanggulangan bencana di Indonesia telah dilaksanakan oleh berbagai sektor, baik pemerintah maupun non pemerintah, akan tetapi dirasakan masih belum optimal dan terkesan lamban. Hal ini disebabkan oleh berbagai alasan, antara lain sumber daya manusia sebagai pelaku penanggulangan bencana belum memadai, penanganannya bersifat parsial, sektoral dan kurang terpadu, dan masih berorientasi pada upaya tanggap darurat serta kurangnya kesadaran warga masyarakat dalam memelihara lingkungan dan kesadaran dalam mengantisipasi datangnya bencana yang saat ini terus-menerus terjadi (Trsinamansyah \& Nurjanah, 2010).

Bencana yang terjadi di Indonesia telah menimbulkan dampak yang cukup besar pada berbagai sektor salah satunya adalah sektor pendidikan. Di sektor pendidikan, bencana dapat berdampak pada bangunan sekolah dan infrastruktur sekolah, termasuk siswa dan guru serta komponen sekolah lainnya yang merupakan bagian dari komunitas sekolah. Sektor pendidikan memiliki peran penting dalam menghadapi berbagai tantangan yang diakibatkan oleh terjadinya bencana dan dalam mencegah bahaya bencana. Dengan melakukan pengkajian terhadap bahaya dan risiko, melakukan perencanaan berdasarkan hasil kajian tersebut, melakukan perlindungan fisik dan lingkungan, serta membuat rencana kesiapsiagaan, maka bahaya dapat dicegah untuk tidak menjadi bencana.

Sekolah merupakan lembaga tempat berbagi pengetahuan dan keterampilan, sehingga harapan bahwa sekolah menjadi panutan dalam melakukan pencegahan bencana menjadi tinggi. Keberhasilan mitigasi bencana merupakan salah satu ujian utama terhadap keberhasilan pendidikan yang diberikan dari generasi ke generasi. Sekolah aman yang komprehensif dapat dicapai melalui kebijakan dan perencanaan yang sejalan dengan manajemen bencana di tingkat nasional, provinsi, kabupaten/kota dan di tingkat sekolah. Sekolah aman yang komprehensif ini ditopang oleh tiga pilar sebagai berikut:1) fasilitas sekolah aman, 2) manajemen bencana di sekolah, dan 3) pendidikan pencegahan dan pengurangan risiko bencana (UNICEF, 2015).

Sekolah dipercaya memiliki pengaruh langsung terhadap generasi muda, yaitu dalam menanamkan nilai-nilai budaya dan menyampaikan pengetahuan tradisional dan konvensional kepada generasi muda. Untuk melindungi anak-anak dari ancaman bencana alam diperlukan dua prioritas berbeda namun tidak bisa dipisahkan aksinya yaitu pendidikan untuk mengurangi risiko bencana dan keselamatan dan keamanan sekolah. Sekolah juga harus mampu melindungi anak-anak dari suatu kejadian bencana alam. Investasi dalam memperkuat struktur gedung sekolah sebelum suatu bencana terjadi, akan mengurangi biaya/anggaran jangka panjang, melindungi generasi muda penerus bangsa, dan memastikan kelangsungan kegiatan belajar mengajar setelah kejadian bencana. Menyelenggarakan pendidikan tentang risiko bencana ke dalam kurikulum sekolah sangat membantu dalam membangun 
kesadaran akan isu tersebut di lingkungan masyarakat (UNICEF, 2015).

Oleh karena itu upaya untuk meminimumkan risiko bencana di sekolah menjadi hal yang utama, salah satunya melalui peningkatan kesiapsiagaan komunitas sekolah. Salah satu upaya meningkatkan kesiapsiagaan menghadapi bencana adalah melalui peningkatan kapasitas komunitas sekolah yang terdiri dari unsur siswa, guru dan komponen sekolah lainnya. Peningkatan kesiapsiagaan komunitas sekolah dapat dilakukan melalui peningkatan kapasitas sumber daya manusia dan peningkatan kesiapsiagaan dari komponen fisik sekolah seperti bangunan dan infrastruktur lainnya (Triyono et al, 2013).

\section{METODE}

Jenis penelitian ini merupakan penelitian kuantitatif dan desain penelitiannya adalah quasi experiment dengan rancangan yang digunakan adalah one group pre and post test design. Populasi dalam penelitian ini adalah semua guru atau tenaga pendidik dan tenaga non kependidikan di SLB N Pembina Yogyakarta yang berjumlah 60 orang. Teknik pengambilan sampel yang digunakan adalah purposive sampling. Berdasarkan kriteria inklusi dan eksklusi jumlah sampel yang digunakan sebanyak 52 responden. Alat pengumpulan data dalam penelitian ini, penulis menggunakan kuesioner mengadopsi dari Herdwiyanti \& Sudaryono (2013) dan dimensi kesiapsiagaan menurut Sutton \& Tierney (2006) sebanyak 27 item. Kuesioner tersebut digunakan untuk mengukur kesiapsigaan sebelum dan sesudah diberikan pelatihan siaga bencana.

\section{HASIL}

SLB N Pembina Yogyakarta merupakan sekolah luar biasa terbesar ke-2 di Yogyakarta. Berikut ini distribusi frekuensi berdasarkan karakteristik responden serta data pernah diberikan pelatihan siaga bencana atau belum.

Tabel 1. Distribusi Frekuensi Karakteristik Responden di SLB N Pembina Yogyakarta (n=52)

\begin{tabular}{lcc}
\hline \multicolumn{1}{c}{ Responden } & Frekuensi & (\%) \\
\hline Jenis Kelamin & & \\
Laki-laki & 22 & 42,3 \\
Perempuan & 30 & 57,7 \\
Usia & & \\
$25-35$ th & 19 & 36,5 \\
$36-45$ th & 13 & 25 \\
$>46$ th & 20 & 38,5 \\
Pelatihan & & \\
Pernah & 40 & 76,9 \\
Belum & 12 & 23,1 \\
\hline
\end{tabular}

Berdasarkan tabel 1, karakteristik responden sebagian besar berjenis kelamin perempuan sebanyak 30 orang $(57,7 \%)$ dengan mayoritas usia diatas 46 tahun sebanyak 20 orang $(38,5 \%)$ dan sebagian besar pernah mengikuti pelatihan sebanyak 40 orang $(76,9 \%)$. Oleh karena itu, dapat disimpulkan bahwa pengetahuan tentang kebencanaan sudah sangat baik sehingga diharapkan dapat mengurangi risiko yang terjadi ketika terjadi bencana gempa bumi.

Tabel 2. Pelatihan Siaga Bencana Gempa Bumi

Dalam Rangka Pengurangan Risiko Bencana di SLB N Pembina Yogyakarta $(n=52)$

\begin{tabular}{cccccccc}
\hline Peran & \multicolumn{4}{c}{ Pre } & \multicolumn{5}{c}{ Post } & $\mathrm{p}$ \\
\cline { 2 - 6 } $\begin{array}{c}\text { Komunitas } \\
\text { sekolah }\end{array}$ & $\mathrm{f}$ & Mean & SD & $\mathrm{f}$ & Mean & SD & \\
& 52 & 101,06 & 8,79 & 52 & 102,52 & 12,1 & $>0.001$ \\
\hline
\end{tabular}

Berdasarkan tabel 2, dapat diketahui nilai $\mathrm{p}>$ 0,001 yang berarti tidak ada perbedaan makna secara statistik antara sebelum diberikan pelatihan dan sesudah diberikan pelatihan. Selisih nilai mean pre dan post adalah 1,46 yang menunjukkan adanya peningkatan kesiapsiagaan setelah diberikan pelatihan, namun masuk dalam kategori lemah.

Tabel 3. Domain Tindakan Kesiapsiagaan Bencana Sebelum dan Sesudah diberikan Pelatihan Siaga Bencana di SLB N Pembina Yogyakarta $(n=52)$

\begin{tabular}{ccccc}
\multicolumn{4}{c}{ Yogyakarta $(\mathrm{n}=52)$} \\
\hline Kategori & \multicolumn{2}{c}{ Pre } & \multicolumn{2}{c}{ Post } \\
\cline { 2 - 5 } & $\mathrm{f}$ & $(\%)$ & $\mathrm{f}$ & $\%$ \\
\hline
\end{tabular}

Mampu melindungi diri

dan menghindari risiko

bahaya

\begin{tabular}{lllll} 
Baik & 30 & 57,7 & 37 & 71,2 \\
Kurang & 22 & 42,3 & 15 & 28,8 \\
\hline
\end{tabular}

Mampu mengidentifikasi

bahaya, risiko, kerentanan

dan dampak bencana yang

ada di lingkungan sekitar

\begin{tabular}{lcccc} 
Baik & 38 & 73 & 45 & 86,5 \\
Kurang & 14 & 27 & 7 & 13,5 \\
\hline $\begin{array}{l}\text { Memiliki informasi, } \\
\text { pengetahuan dan } \\
\text { kemampuan untuk }\end{array}$ & & & & \\
$\begin{array}{l}\text { merespon kejadian } \\
\text { bencana }\end{array}$ & & & & \\
& & & & \\
Baik & & & & \\
Kurang & 27 & 51,9 & 38 & 73,1 \\
\hline Bertindak tepatguna & 25 & 48 & 14 & 26,9 \\
\hline
\end{tabular}

Bertindak tepat guna 


\begin{tabular}{lllll}
\hline $\begin{array}{l}\text { untuk mencegah } \\
\text { kehilangan/kerugian atau } \\
\text { kerusakan harta benda }\end{array}$ & & & & \\
& & & & \\
Baik & 19 & 36,9 & 28 & 53,8 \\
Kurang & 33 & 63,5 & 24 & 46,2 \\
\hline $\begin{array}{l}\text { Mengembangkan } \\
\text { kemampuan untuk }\end{array}$ & & & & \\
mempertahankan diri & & & & \\
sendiri selama bencana & & & & \\
& & & & \\
Baik & 24 & 46,2 & 29 & 55,8 \\
Kurang & 28 & 53,8 & 23 & 44,2 \\
\hline
\end{tabular}

Berdasarkan tabel 3, terdapat 5 (lima) domain tindakan dalam kesiapsiagaan bencana. Kelima domain tersebut mengalami peningkatan setelah diberikan pelatihan siaga bencana. Tindakan yang paling mengalami peningkatan dalam rangka pengurangan risiko bencana yang dilakukan komunitas sekolah adalah memiliki informasi, pengetahuan dan kemampuan untuk merespon kejadian bencana. Sebelum diberikan pelatihan siaga bencana sebanyak 51,9\% dan meningkat setelah diberikan pelatihan sebanyak $73,1 \%$.

Sedangkan tindakan yang paling dominan dilakukan saat pelatihan adalah mampu mengidentifikasi bahaya, risiko, kerentanan dan dampak bencana yang ada di lingkungan sekitar. Sebelum diberikan pelatihan siaga bencana sebanyak 73\% dan meningkat setelah diberikan pelatihan bencana sebanyak $86,5 \%$.

\section{PEMBAHASAN}

\section{Tindakan Kesiapsiagaan Bencana}

SLB N Pembina Yogyakarta termasuk sekolah luar biasa terbesar di Yogyakarta yang memiliki 230 siswa berkebutuhan khusus. Berdasarkan tabel 1, sebagian besar responden pernah mengikuti pelatihan sebanyak 40 orang (76,9\%). Dari data tersebut, secara umum aspek pengetahuan tentang kesiapsiagaan bencana gempa bumi, pengetahuan komunitas sekolah sudah sangat bagus. Namun ada beberapa guru dan tenaga non kependidikan yang belum mendapatkan pelatihan siaga bencana sebanyak 12 orang $(23,1 \%)$. Hasil wawancara dengan beberapa guru menyatakan bahwa mereka yang belum mendapatkan pelatihan adalah guru baru.

SLB N Pembina pernah melakukan pelatihan siaga bencana pada tahun 2006 setelah bencana gempa bumi terjadi dan pelatihan kembali dilakukan pada tahun 2017. Jarak waktu antara pelatihan pertama dan kedua adalah 11 tahun. Pada tabel 2 dapat diketahui bahwa ada peningkatan kesiapsiagaan setelah diberikan pelatihan, namun masuk dalam kategori lemah. Oleh karena itu, pelatihan atau simulasi diharapkan dapat dilaksanakan secara berkelanjutan, setiap 3-6 bulan sekali (Yustisia dkk, 2019).

Upaya pengurangan risiko bencana terdapat pada tabel 2 yang menunjukkan sebelum dan sesudah diberikan pelatihan siaga bencana terdapat peningkatan pengetahuan sebanyak 1,46. Peningkatan ini tidak mengalami perbedaan bermakna karena sebagian besar guru-guru di SLB telah mendapatkan pelatihan siaga bencana. Namun pelatihan ini perlu untuk tetap dilakukan sebagai upaya dalam mengupdate pengetahuan tentang bencana dan memfasilitasi guru-guru yang belum pernah mendapatkan pelatihan. Pengetahuan terhadap bencana merupakan alasan utama seseorang untuk melakukan kegiatan perlindungan atau upaya kesiapsiagaan yang ada. Pengetahuan yang dimiliki mempengaruhi sikap dan kepedulian masyarakat untuk siap dan siaga dalam mengantisipasi bencana, terutama bagi mereka yang bertempat tinggal di daerah yang rentan terhadap bencana alam.

Berdasarkan tabel 3, sebelum diberikan pelatihan siaga bencana pada domain bertindak tepat guna untuk mencegah kerusakan dan kehilangan harta benda serta kemampuan dalam mempertahankan diri selama bencana termasuk dalam kategori kurang. Namun setelah diberikan pelatihan siaga bencana menunjukkan hasil dalam kategori baik terhadap dua domain tersebut yang artinya terdapat peningkatan kesiapsiagaan dalam menghadapi bencana. Bertindak tepat guna dan berdaya guna dalam menghadapi bencana menurut keputusan KEMHAN (2016) antara lain adalah ikut serta dalam mengikuti pelatihan siaga bencana, rencana kedaruratan dengan melatih anggota keluarga dalam menghadapi gempa bumi, pembentukan kelompok aksi penyelamatan bencana dan pertolongan pertama. Hal ini ditunjukkan pada tabel 1 bahwa sebanyak 76,9\% guru telah berpartisipasi dalam mengikuti pelatihan siaga bencana. Selain itu sekolah juga sudah membentuk unit siaga bencana walaupun belum optimal didalam pelaksanaannya namun dengan diberikan pelatihan siaga bencana dapat merefresh kembali pengetahuan yang didapatkan dan menumbuhkan motivasi dalam mewujudkan sekolah siaga bencana.

$$
\text { Menurut peraturan BNPB (2012) }
$$
kemampuan/kapasitas adalah sumber daya, pengetahuan, keterampilan, dan kekuatan yang dimiliki seseorang atau masyarakat yang memungkinkan mereka untuk mempertahankan dan mempersiapkan diri, mencegah, dan memitigasi, menanggulangi dampak buruk, atau 
dengan cepat memulihkan diri dari bencana. Kemampuan yang baik didukung oleh pengetahuan dan keterampilan yang dalam hal ini guru-guru mendapatkan pelatihan siaga bencana. Latihan kesiapsiagaan dalam menghadapi bencana merupakan salah satu upaya mendasar untuk meningkatkan kewaspadaan dan kesadaran menumbuhkan budaya siaga (BNPB, 2017).

Berdasarkan tabel 3, kesiapsiagaan sekolah termasuk dalam kategori baik pada parameter sikap dan tindakan. Namun untuk parameter kebijakan sekolah, perencanaan kesiapsiagaan dan mobilisasi sumber daya belum terimplementasi. Tujuan dari Sekolah Siaga Bencana (SSB) adalah untuk menciptakan kesiapsiagaan dan budaya aman di lingkungan sekolah serta membangun kekuatan setiap elemen sekolah untuk Pengurangan Risiko Bencana-PRB (KPB, 2011). Parameter kesiapsiagaan sekolah, meliputi: 1. Sikap dan tindakan. Sikap dan tindakan adalah dasar dari adanya persepsi, pengetahuan dan keterampilan yang dimiliki. SSB ingin membangun kemampuan seluruh komunitas sekolah, baik individu maupun kelompok, untuk menghadapi bencana secara cepat dan tepat guna; 2. Kebijakan sekolah. Kebijakan sekolah adalah keputusan yang dibuat secara formal oleh sekolah mengenai hal-hal yang perlu didukung dalam pelaksanaan PRB di sekolah, baik secara khusus maupun terpadu. Keputusan tersebut bersifat mengikat. Pada praktiknya, kebijakan sekolah adalah landasan, panduan, arahan pelaksanaan kegiatan terkait dengan PRB di sekolah; 3. Perencanaan kesiapsiagaan. Perencanaan kesiapsiagaan bertujuan untuk menjamin adanya tindakan cepat dan tepat guna pada saat terjadi bencana dengan memasukan dan mempertimbangkan sistem penanggulangan bencana di daerah dan disesuaikan kondisi wilayah setempat. Bentuk atau produk dari perencanaan ini adalah dokumen-dokumen, seperti protap kesiapsiagaan, rencana kedaruratan, dan dokumen pendukung termasuk sistem peringatan dini yang disusun dengan mempertimbangkan akurasi dan kontekstualisasi lokal; dan 4. Mobilisasi sumber daya. Sekolah harus menyiapkan sumber daya manusia, sarana, dan prasarana, serta finansial dalam pengelolaan untuk menjamin kesiapsiagaan bencana sekolah. Mobilisasi sumber daya didasarkan pada kemampuan sekolah dan pemangku sekolah. Keempat parameter tersebut tidak berdiri sendiri, melainkan saling terkait satu dengan lainnya (Rofidah, 2017).

Penerapan pengetahuan dan sikap ke dalam sistem pendidikan (sekolah) merupakan salah satu sumber dan penyebaran informasi yang efektif kepada masyarakat. Siswa juga diharapkan dapat meneruskan pesan kepada orang tua dan anggota keluarga lainnya. Interaksi PRB ke dalam kurikulum formal maupun informal telah dilakukan di berbagai tingkatan. Intervensi kegiatan yang lainnya yang perlu dilakukan secara berkelanjutan adalah peningkatan kesiapsiagaan komunitas sekolah dengan pelaksanaan peningkatan kesadaran dan kapasitas guru dan siswa dalam menganalisis risiko dan melakukan pengorganisasian keadaan tanggap darurat termasuk mekanisme transisi tanggung jawab dari pihak sekolah kepada orang tua terhadap siswa di masa bencana/pasca bencana (Hidayati, 2009).

Bencana alam sulit diprediksi, baik waktu terjadi maupun dampaknya. Oleh sebab itu, penanganan bencana yang efektif perlu disiapkan. Penanganan bencana yang efektif dapat mengurangi dampak dari bencana yang terjadi (INNE, 2010). Sekolah juga harus memiliki kesiapan dalam menghadapi bencana. Saat terjadi bencana, setiap komponen sekolah harus siap sehingga dapat berkoordinasi secara efektif dan berbagi informasi yang sama (Reeves et al., 2010).

\section{Peran Komunitas Sekolah}

Pemerintah Indonesia telah menetapkan Undang-Undang No. 24 Tahun 2007 tentang Penanggulangan Bencana yang menekankan bahwa Penanggulangan Bencana tidak hanya terpaku pada tahap tanggap darurat saja, tetapi juga mencakup tahap pra bencana (kesiapsiagaan) dan pasca bencana (pemulihan), dimana UndangUndang tersebut secara jelas menyatakan bahwa setiap orang berhak mendapatkan pendidikan, pelatihan, penyuluhan, dan keterampilan dalam penyelenggaraan penanggulangan bencana, baik dalam situasi tidak terjadi bencana maupun situasi terdapat potensi bencana (UNICEF, 2015).

Bencana yang terjadi di sekolah dapat didefinisikan sebagai segala kejadian yang mengakibatkan titik balik, seringkali berwujud penderitaan, tekanan, atau ketidakteraturan fungsi secara fisik dan atau psikologis (Reeves et al., 2010). Keamanan sekolah adalah tugas dan tanggung jawab seluruh komunitas sekolah. Upaya ini membutuhkan kepemimpinan dan koordinasi oleh pihak pengelola sekolah, dan memerlukan keterlibatan dan partisipasi dalam semua bidang oleh komunitas sekolah. Pentingnya pengupayaan kesiapsiagaan bencana di sekolah merupakan agenda penting bersama sebagai upaya dan tanggung jawab dari komunitas sekolah dan para pemangku kepentingan sekolah. Komunitas sekolah adalah semua orang yang berada dan terlibat dalam kegiatan belajar mengajar: siswa, guru, tenaga kependidikan dan kepala sekolah. 
Pemangku kepentingan sekolah adalah seluruh komponen masyarakat yang berkepentingan dengan sekolah, baik warga masyarakat maupun lembaga/institusi masyarakat sekitar sekolah (Rofidah, 2017).

Sekolah Siaga Bencana (SSB) adalah sekolah yang memiliki kemampuan untuk mengatasi bencana di lingkungan sekitarnya yang diukur dari rencana penanggulangan bencana (pra-bencana, bencana darurat, dan setelah bencana), logistik, keamanan di lingkungan belajar, infrastruktur, sistem darurat, prosedur operasional yang telah distandarkan, dan sistem peringatan dini (KPB, 2011). Guru dan tenaga kependidikan di sekolah adalah komponen yang paling penting untuk menciptakan sekolah aman. Oleh karena itu para guru dan tenaga kependidikan perlu memiliki keterampilan dan pengetahuan tentang sekolah aman, prinsip dan parameter yang dipakai, program sosialisasi kepada peserta didik dan komponen sekolah lainnya, termasuk orang tua dan pejabat pemerintah setempat. Kegiatan pendidikan kebencanaan di sekolah menjadi strategi efektif, dinamis, dan berkesinambungan dalam upaya penyebarluasan pendidikan kebencanaan. Upaya sistemik, terukur dan implementatif dalam meningkatkan kemampuan komunitas sekolah, niscaya mampu mengurangi dampak risiko bencana di sekolah (Rofidah, 2017).

Federal Emergency Management Agency (FEMA) membagi tanggung jawab kepala sekolah, guru, tenaga administratif dan pihak lainnya yang terkait pada kesiapsiagaan sekolah dalam MultiPhase Comprehensive Safe School Plans (FEMA, 2011). Kemampuan setiap personil sangat berpengaruh pada kesuksesan SSB. Inter-Agency Network for Education in Emergencies (INEE) pada Planning in an Emergency Checklist mencantumkan standar minimum untuk sekolah dalam menanggulangi bencana. Pendidikan mengenai bencana perlu dimasukkan ke dalam sistem pendidikan, kurikulum dan pengajaran, serta kesinambungan pendidikan dalam situasi bencana (INNE, 2004).

Langkah awal sebagai upaya didalam pengurangan risiko bencana yang dilakukan adalah pemberian pengetahuan dan pelatihan siaga bencana kepada guru di sekolah dengan harapan bahwa guru-guru dapat memberikan edukasi kepada siswa-siswanya di sekolah. Hal tersebut didukung oleh konsorsium pendidikan bencana Indonesia (2011) bahwa sekolah merupakan basis dari komunitas anak-anak. Sekolah merupakan wahana efektif dalam memberikan efek tular-informasi, pengetahuan, dan keterampilan kepada masyarakat terdekatnya. Dengan demikian, kegiatan pendidikan kebencanaan di sekolah menjadi strategi efektif, dinamis, dan berkesinambungan dalam upaya penyebarluasan pendidikan kebencanaan. Upaya sistematis, terukur, dan implementatif dalam meningkatkan kemampuan komunitas sekolah, niscaya mampu mengurangi dampak risiko bencana di sekolah.

\section{SIMPULAN}

Pendidikan Pencegahan dan Pengurangan Risiko Bencana atau lebih sering disebut sebagai Pendidikan Pengurangan Risiko Bencana (PRB) merupakan sebuah kegiatan jangka panjang dan merupakan bagian dari pembangunan berkelanjutan. Melalui pendidikan diharapkan agar upaya pengurangan risiko bencana dapat mencapai sasaran yang lebih luas dan dapat dikenalkan secara lebih dini kepada seluruh peserta didik, yang pada akhirnya dapat berkontribusi terhadap kesiapsiagaan individu maupun masyarakat terhadap bencana. Berdasarkan hal tersebut, perlu adanya pengintegrasian pengurangan risiko bencana ke dalam kurikulum sekolah.

Kunci keberhasilan dari PRB adalah menciptakan kestabilan kesiapsiagaan pada waktu sebelum terjadi bencana (Graham et al., 2006). Pengalaman akan bencana yang berulang tidaklah cukup, maka pelatihan yang terintegrasi dan sosialisasi lebih lanjut terhadap SSB sangatlah diperlukan. Dengan memiliki kesiapsiagaan menghadapi bencana diharapkan setiap orang mampu untuk mengurangi ancaman dan kerentanan dalam menghadapi bencana melalui: a) pengenalan dan pemantauan risiko bencana; b) partisipasi dalam perencanaan penanggulangan bencana; c) pengembangan budaya sadar bencana: d) peningkatan komitmen terhadap pelaku penanggulangan bencana; dan e) penerapan upaya fisik, non-fisik, dan pengaturan penanggulangan bencana (UNICEF, 2015).

\section{REFERENSI}

BNPB (2017) Buku Pedoman Latihan Kesiapsiagaan Bencana: Membangun Kesadaran, Kewaspadaan, Kesiapsiaagaan Dalam Menghadapi Bencana, Jakarta: BNPB.

Bustami, Del Afriadi. (2011). Modul Pelatihan Dasar Manajemen Penanggulangan Bencana. Jakarta. UNDP.

FEMA (2011), Sample school emergency operations plan. Available on : https://training.fema.gov/programs/emisc hool/el361toolkit/assets/sampleplan.pdf 
Graham, J., Shirm, S., Liggin, R., Aitken, M. E., \& Dick, R. (2006). Mass-casualty events at schools: A national preparedness survey. Pediatrics, 117(1). https://doi.org/10.1542/peds.2005-0927

Herdwiyanti A. F \& Sudaryono. 2013. Perbedaan Kesiapsiagaan Menghadapi Bencana Ditinjau dari Tingkat Self-Efficacy pada Anak Usia Sekolah Dasar di Daerah Dampak Bencana Gunung Kelud. Jurnal Psikologi Kepribadian dan Sosial 2(1)

Hidayati, Deny dkk. (2006). Kajian Kesiapsiagaan Masyarakat Dalam Mengantisipasi Bencana Gempa \& Tsunami di Indonesia. LIPI UNESCO - ISDR. Jakarta.

Hidayati, Sri dkk. (2009). Modul Pelatihan Pengintegrasian Pengurangan Risiko Bencana (PRB) ke dalam Sistem Pendidikan. Pusat Kurikulum Badan Penelitian dan Pengembangan Kriteria Pendidikan Nasional. Jakarta.

IFC (2010) Disaster and Emergency Preparedness: Guidance for Schools. International Finance Corporation: World Bank Group.

The Inter-Agency Network for Education in Emergencies. (2004). INEE minimum standards for education in emergencies, chronic crisis and early reconstruction: Inter-Agency Network for Education in Emergencies. Retrieved from http://www.unicef.org/violencestudy/pdf/ min standards education emergencies.pdf

International Network for Education in Emergencies. (2010). Minimum standards for education: Preparedness, Response, Recovery. An International Network for Education in Emergencies, 43. Retrieved from www.ineesite.org

Keputusan Kementrian Pertahanan (2016) Pencegahan Dan Mitigsi. Available on: https://www.kemhan.go.id/badiklat/wpcontent/uploads/2017/12/HANJARPENCEGAHAN-DAN-MITIGASIREVISIutkPDF.pdf

Konsorsium Pendidikan Bencana Indonesia (2011) Kerangka Kerja Sekolah Siaga Bencana. Jakarta: Konsorsium pendidikan bencana Indonesia.

Peraturan Kepala BNPB (2012) Pedoman Umum Desa/Kelurahan Tangguh Bencana Nomor 1 Tahun 2012.

Reeves, M.A, Kanan, L.M \& Plog, A.E (2010) Comprehensive planning for safe learning environments. A school professional's guide to integrating physical and psychological safety -Prevention through recovery, Abingdon, Routledge, 339 pp.

Rofidah, Siti. (2017). Kesiapsiagaan Warga Sekolah Dalam Upaya Pengurangan Risiko Bencana Tanah Longsor. Jurusan Geografi Fakultas Ilmu Sosial Universitas Negeri Semarang.

Safety Sign Indonesia. (2018) Panduan Kesiapsiagaan Bencana Alam. Available on: www.safetysign.co.id

Trisnamansyah, S \& Nurjanah. (2010). Model Pelatihan Penanggulangan Bencana Dalam Meningkatkan Kemandirian Masyarakat. Jurnal Penelitian dan Pengembangan Kesejahteraan Sosial vol. 15, No. 02.

Triyono, Putri, B.R, Koswara, A \& Adhitya, V (2013). Panduan Penerapan Sekolah Siaga Bencana, Jakarta : Pusat Penelitian Geoteknologi Lembaga Ilmu Pengetahuan Indonesia (LIPI).

Undang-Undang Republik Indonesia (2007) Penanggulangan Bencana No 24.

UNICEF. (2015). Pilar 2- Manajemen Bencana di Sekolah. Jakarta: Kementrian Pendidikan dan Kebudayaan.

UNICEF. (2015). Pilar 3 -Pendidikan Pencegahan dan Pengurangan Risiko Bencana. Jakarta: Kementrian Pendidikan dan Kebudayaan.

Yustisia, N; Aprilatutini, T; Utama, T.A. (2019). Pengaruh Simulasi Menghadap Bencana Gempa Bumi Terhadap Kesiapsiagaan Siswa SDN 86 Kota Bengkulu. Journal of Nursing and Public Health, Vol. 7 No. 2. 